\title{
Digenetic trematodes of some teleost fish off the Mudanya Coast (Sea of Marmara, Turkey)
}

\author{
M. C. OGUZ ${ }^{1}$ R. A. BRAY ${ }^{2}$ \\ ${ }^{1}$ Biology Department, Faculty of Science and Art, Ataturk University, Erzurum, Turkey; \\ E-mail: mcoguz@atauni.edu.tr; m_c_oguz@hotmail.com; ${ }^{2}$ Department of Zoology, Natural History Museum, \\ Cromwell Road, London SW7 5BD, UK
}

\begin{abstract}
Summary
A total of 200 fishes belonging to nine species were sampled from the Sea of Marmara. Thirteen trematode species were recorded in the intestine of these hosts: Helicometra fasciata and Diphterostomum brusinae in Zosterisessor ophiocephalus; Monascus filiformis in Trachurus trachurus; Dicrogaster purpusilla, Schikhobalotrema sparisomae and Saccocoelium obesum in Liza saliens; Macvicaria alacris, H. fasciata and Gaevskajatrema perezi in Symphodus tinca; Anisocladium fallax and A. capitellum in Uranoscopus scaber; Stephanostomum caducum in Merluccius merluccius; Bucephalus marinus, Stephanostomum gaidropsari and H. fasciata in Gaidopsarus mediterraneus; $H$. fasciata in Scorpaena scrofa and Gobius cobitis.
\end{abstract}

Key words: helminths; Digenea; Mudanya; Sea of Marmara; Turkey

\section{Introduction}

In the recent checklist of parasites of Turkish marine waters, Öktener (2005) records 45 species of digeneans. He uses the checklist to bring to general attention reports from locally available theses, greatly increasing our sparse knowledge of this fauna. Among these theses is that of the senior author (Oguz, 1995) and this paper is an update of those observations, including several re-determinations. These constitute only the second report of Digenea from the Sea of Marmara, the first being Sezen-Akandere (1972) who reported Lepidapedon sengunii Sezen-Akandere, 1972 and L. ricci Sezen-Akandere, 1972 from Trachurus trachurus. Bray and Gibson (1990) synonymised both species with Prodistomum polonii (Molin, 1859), a common parasite of this host.

\section{Material and Methods}

The study area is in north-western Anatolia, $40^{\circ} 22^{\prime} \mathrm{N}, 28^{\circ}$ $52^{\prime} \mathrm{E}$ (Fig. 1). During the study period from November
1990 to May 1993, between 6 and 28 specimens of 9 fish species were collected. The fish were placed in plastic containers containing sea water and then transferred the research laboratory. They were kept in the tanks until examination within 24 hours of collection. Methods adapted and utilised for the helminthological necropsy, and later for the analysis, were routine techniques (Pritchard \& Kruse, 1982). All possible sites of infection were examined for the occurrence of parasites with the aid of a stereo microscope with $\times 12$ and $\times 50$ magnifications. The parasites were fixed with AFA, and then stained with Mayer's carmalum. Data for the prevalence, intensity and abundance are given (see Margolis, et al. 1982). The specimens are deposited in the Biology Department, Faculty of Science and Art, Ataturk University.

\section{Results}

A total of 184 fishes from 9 species Liza saliens (Risso), Gaidopsarus mediterraneus (L.), Gobius cobitis Pallas, Merluccius merluccius (L.), Symphodus tinca (L.), Scorpaena scrofa L., Uranoscopus scaber L., Trachurus tra-

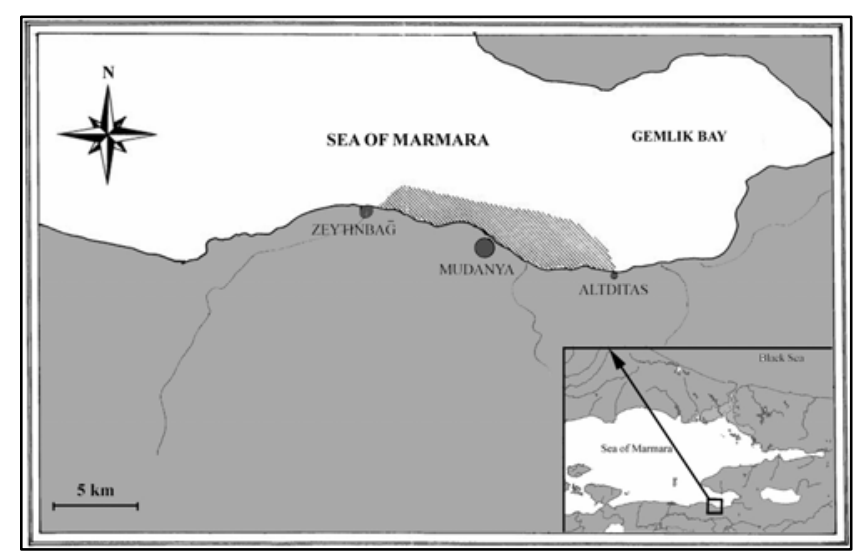

Fig. 1. The research area 
churus (L.) and Zosterisessor ophiocephalus (Pallas) were investigated. 183 individuals of 13 trematode species were identified from the intestine of these species (Table 1). Basic measurements are given in Table 2. various authors. The only description available from this region is that of Saad-Fares (1985), who reported the worm from several mullet species, including Liza saliens, from off the coast of Libya. Other records from this region

Table 1. Digenetic trematodes of some fish species of Mudanya coast, Turkey

\begin{tabular}{lcclc}
\hline Host fish species & $\mathrm{N}$ & $\mathrm{In} \&(\%)$ & Identified parasites group & $\mathrm{Mx}(\mathrm{Mn}) \sum$ \\
\hline Gaidopsarus mediterraneus & 14 & $3(21 \%)$ & Helicometra fasciata & $4(3.3) 10$ \\
Gaidopsarus mediterraneus & 14 & $1(7 \%)$ & Stephanostomum gaidropsari & $1(1) 1$ \\
Gaidopsarus mediterraneus & 14 & $1(7 \%)$ & Bucephalus marinus & $1(1) 1$ \\
Gobius cobitis & 25 & $3(12 \%)$ & Helicometra fasciata & $6(5.3) 16$ \\
Liza saliens & 18 & $3(16 \%)$ & Dicrogaster perpusilla & $5(3.3) 10$ \\
Liza saliens & 18 & $5(27 \%)$ & Saccocoelium obesum & $6(2.4) 12$ \\
Liza saliens & 18 & $5(27 \%)$ & Schikhobalotrema sparisomae & $3(2.0) 10$ \\
Merluccius merluccius & 39 & $1(2 \%)$ & Stephanostomum caducum & $1(1) 1$ \\
Scorpaena scrofa & 17 & $4(23 \%)$ & Helicometra fasciata & $20(10.0) 40$ \\
Symphodus tinca & 14 & $4(28 \%)$ & Helicometra fasciata & $6(3.7) 15$ \\
Symphodus tinca & 14 & $1(7 \%)$ & Macvicaria alacris & $1(1) 1$ \\
Symphodus tinca & 14 & $10(71 \%)$ & Gaevskajatrema perezi & $6(1.2) 12$ \\
Trachurus trachurus & 39 & $8(20 \%)$ & Monascus filiformis & $5(2.5) 20$ \\
Uranoscopus scaber & 16 & $6(37 \%)$ & Anisocladium fallax & $3(1.6) 10$ \\
Uranoscopus scaber & 16 & $7(43 \%)$ & Anisocoelium capitellatum & $4(1.7) 12$ \\
Zosterisessor ophiocephalus & 18 & $6(33 \%)$ & Helicometra fasciata & $3(2.6) 16$ \\
Zosterisessor ophiocephalus & 18 & $1(5 \%)$ & Diphterostomum brusinae & $1(1) 1$ \\
\hline
\end{tabular}

Number of examined fish $(\mathrm{N})$; number of infected fish $(\mathrm{In})$; percentage $(\%)$; maximum $(\mathrm{Mx})$; mean $(\mathrm{Mn})$ and total $\left(\sum\right)$ number of parasite

Table 2. Measurement (length $\mathrm{x}$ width) of the digenetic trematodes of the fish species caught in Mudanya coast, Turkey

\begin{tabular}{lccccccc}
\hline Parasite Species & $\mathrm{Bd}$ & $\mathrm{Ph}$ & $\mathrm{Os}$ & $\mathrm{Vs}$ & $\mathrm{Tt}(\mathrm{A}-\mathrm{P})$ & $\mathrm{Ov}$ & Egg \\
\hline S. sparisomae & $1854 \times 739$ & $84 \times 110$ & $156 \times 167$ & $233 \times 250$ & $507 \times 900$ & $100 \times 147$ & $87 \times 55$ \\
B. marinus & $1400 \times 494$ & $60 \times 67$ & $\mathrm{n} / \mathrm{a}$ & $278 \times 308^{*}$ & $207 \times 203-141 \times 230$ & $140 \times 106$ & $29 \times 14$ \\
H. fasciata & $3007 \times 1148$ & $101 \times 120$ & $241 \times 225$ & $365 \times 379$ & $234 \times 612-322 \times 544$ & $73 \times 360$ & $18 \times 58$ \\
G. perezi & $1146 \times 652$ & $66 \times 101$ & $100 \times 160$ & $259 \times 292$ & $166 \times 226-196 \times 257$ & $140 \times 152$ & $58 \times 89$ \\
M. alacris & $932 \times 352$ & $54 \times 70$ & $108 \times 118$ & $200 \times 220$ & $130 \times 140-140 \times 150$ & $60 \times 80$ & $24 \times 70$ \\
D. perpusilla & $936 \times 356$ & $59 \times 83$ & $91 \times 120$ & $127 \times 127$ & $168 \times 222$ & $87 \times 121$ & $19 \times 41$ \\
S. obesum & $1666 \times 500$ & $104 \times 125$ & $30 \times 60$ & $120 \times 153$ & $96 \times 216$ & $100 \times 180$ & $27 \times 43$ \\
D. brusinae & $1040 \times 486$ & $32 \times 90$ & $153 \times 173$ & $288 \times 360$ & $100 \times 130-84 \times 130$ & $100 \times 110$ & $22 \times 27$ \\
S. caducum & $4804 \times 508$ & $80 \times 164$ & $170 \times 200$ & $46 \times 95$ & $320 \times 520-280 \times 480$ & $168 \times 264$ & $40 \times 63$ \\
S. gaidropsari & $5783 \times 548$ & $110 \times 90$ & $114 \times 140$ & $180 \times 220$ & $480 \times 600-470 \times 700$ & $126 \times 256$ & No egg \\
M. filiformis & $4633 \times 487$ & $153 \times 244$ & $212 \times 223$ & $194 \times 212$ & $199 \times 210-202 \times 214$ & $178 \times 212$ & $28 \times 21$ \\
A. fallax & $2714 \times 316$ & $59 \times 99$ & $109 \times 129$ & $170 \times 170$ & $96 \times 188-105 \times 207$ & $75 \times 82$ & No egg \\
A. capitellatum & $3006 \times 344$ & $55 \times 76$ & $168 \times 224$ & $55 \times 60$ & $168 \times 224-151 \times 204$ & $106 \times 120$ & $19 \times 8$ \\
\hline
\end{tabular}

* Rhynchus; $\mathrm{Bd}$ - body; $\mathrm{Ph}$ - pharynx; Os - oral sucker; Vs - ventral sucker; $\mathrm{Tt}$ - testes (A - anterior; $\mathrm{P}$ - posterior); Ov - ovary

\section{Discussion}

Systematic observations on parasites found:

Family Haplosplanchnidae

Genus Schikhobalotrema Skrjabin \& Gushanskaya, 1955 Schikhobalotrema sparisomae (Manter, 1937) Skrjabin \& Gushanskaya, 1955

This species appears to be that known by the above name and reported in mullets in the Mediterranean basin by 162 include Solonchenko and Tkachuk (1985) from L. auratus in the Sea of Azov, and Dmitrieva and Gaevskaya (2001) from Mugil cephalus in the Black Sea. Unnamed Schickhobalotrema species are reported in Mediterranean basin mullet, but not L. saliens, by various authors, including the report from three species of mullet off the Aegean coast of Turkey by Altunel (1982). This species is most frequently reported in scarid fishes in the north-western Atlantic (Nahhas et al., 1997), having been initially found in Sparisoma spp. off Florida (Manter, 1937). 
The record of Piriforma sp. from Zosterisessor ophiocephalus by Oguz (1995) relates to a single specimen which we have re-examined. Our further observation is that it is a heavily-flattened haplosplanchnid which is not identifiable further in this condition.

Family Bucephalidae Poche, 1907

Genus Bucephalus Baer, 1827

\section{Bucephalus marinus Vlasenko, 1931}

This material was not mentioned in Öktener (2005). This species is commonly reported from Gaidropsarus mediterraneus (syn. Onos tricirratus), having been originally described from this host in the Black Sea (Vlasenko, 1931). Since then it has been reported from the Black Sea by Osmanov (1940), Dolgikh and Naidenova (1968), Nikolaeva and Solonchenko (1970), Lushchina (1985), Naidenova et al. (2002) and Gaevskaya and Korniychuk (2003), the Mediterranean off Greece by Papoutsoglou (1976). The record of this species in the Western Mediterranean by Bartoli et al. (2005) is now thought to refer to Rhipidocotyle genovi Dimitrov, Kostadinova \& Gibson, 1996 (see Bartoli et al., in press).

Family Opecoelidae Ozaki, 1925

Genus Helicometra Odhner, 1902

Helicometra fasciata (Rudolphi,1819) Odhner,1902

This record includes that of $H$. insolata [sic] (Polyansky, 1955) by Oguz (1995) and Öktener (2005). Enzyme electrophoresis indicated to Reversat et al. (1989) and Reversat et al. (1991) that morphologically indistinguishable Helicometra forms constituted a complex of three species. The species they reported in Scorpaena scrofa, Symphodus tinca and Zosterisessor ophiocephalus in the Western Mediterranean was, however, considered to be $H$. fasciata. Korniychuk (1999, 2000a), in studies of the morphological variation within $H$. fasciata, also reported it from $S$. tinca, We are, therefore, identifying these forms as $H$. fasciata, well aware of the fact that many workers consider this a species complex whose constituent species are not distinguishable by morphology alone (Aken'Ova et al., 2005). Several other authors have reported $H$. fasciata in the five host species reported here from localities in the Mediterranean basin (see the Natural History Museum Host-parasite database on: http:/www.nhm.ac.uk/research-curation/ projects/host-parasites/database). Bartoli et al. (2005) reported forms of Helicometra from three of these hosts in the Western Mediterranean, those from S. scrofa they called 'form 2', those from G. mediterraneus they called 'form 3' and both 'forms' were reported from $S$. tinca.

Genus Gaevskajatrema Gibson \& Bray, 1982 Gaevskajatrema perezi (Mathias, 1926) Gibson and Bray, 1982

(syns. Plagioporus pontica Koval, 1966, Gaevskajatrema pontica (Koval, 1966) Machkevsky, 1990)

Plagiporus pontica was described from several labrids, including Symphodus (= Crenilabrus) tinca in the Black Sea (Koval, 1966). Gibson and Bray (1982) considered it to be conspecific with Gaevskajatrema perezi from various labrids in the north-eastern Atlantic Ocean (Mathias, 1926; Gibson \& Bray, 1982). Gaevskaya and Solonchenko (1989) also adopted this synonymy, reporting G. perezi from $S$. tinca in the Black Sea. Further records of this parasite from this host in the Black Sea include Machkevsky (1990), who used the combination Gaevskajatrema pontica for the first time as far as we are aware, and Korniychuk (2000b, 2001).

Genus Macvicaria Gibson \& Bray, 1982

Macvicaria alacris (Looss, 1901) Gibson and Bray, 1982

This material, listed as Plagioporus dogieli (Pogorelt'seva, 1975) by Oguz (1995) and Öktener (2005), is re-identified here. M. alacris was described originally by Looss (1901a) from labrids off Trieste in the Adriatic Sea, has been reported several times from Symphodus tinca; from the Black Sea (Pogorelt'seva, 1952; Gaevskaya \& Korniychuk, 2003), the Adriatic Sea (Sey, 1970) and the western Mediterranean (Sasal et al., 1999; Bartoli et al., 2005). Gibson and Bray (1982) figured the worm from several hosts in the northeastern Atlantic and erected the new genus Macvicaria, with this species as its type-host.

Family Haploporidae Nicoll, 1914

Genus Dicrogaster Looss, 1902

Dicrogaster perpusilla Looss, 1902

(syn. Dicrogaster contracta Looss, 1902)

A recent study by Sarabeev and Balbuena (2003) has demonstrated the synonymy of $D$. perpusilla (the type-species of the genus) and D. contracta, based on morphological variability. The species has been known almost exclusively as D. contracta and, as such, has been reported in Liza saliens by Solonchenko $(1976,1982)$ and Solonchenko and Tkachuk (1985) from the Sea of Azov, by Ibragimov (1988) from the Caspian Sea and by Fares and Maillard (1974) and Merella and Garippa (2001) from the western Mediterranean Sea.

Genus Saccocoelium Looss, 1902

Saccocoelium obesum Looss, 1902

Overstreet and Curran (2005) pointed out that Dawes (1956) and Fischthal and Kuntz (1963) [to which they could have added others, e.g. Markevich (1951)] considered $S$. tensum Looss, 1902 a synonym of $S$. obesum, but they also pointed out that Fares and Maillard (1974) showed that life-history stages in addition to morphological differences indicated the validity of both species. The distinctness of these forms have generally been recognised by later studies, including the redescriptions by Radujkovic et al. (1989) and the review by Gaevskaya and Dmitrieva (1993). The species has been reported from Liza saliens by Mikailov (1958) and Ibragimov (1988) in the Caspian Sea, Gaevskaya and Dmitrieva (1993) from the Black Sea and 
Fares and Maillard (1974) and Merella and Garippa (1998) from the western Mediterranean. Both $S$. obesum and $S$. tensum have been reported from the Aegean Sea coast by Altunel (1982), but not in L. saliens.

\section{Family Zoogonidae Odhner, 1902}

Genus Diphterostomum Stossich, 1903

Diphterostomum brusinae (Stossich, 1888) Stossich, 1903 As Bray and Gibson (1986) pointed out, this species is reported mostly from the Mediterranean and Black Seas, but is also recorded in a wide variety of sites in the Atlantic, Indian and Pacific Oceans. There must be considerable doubt as to whether all the records refer to this species, but we have no reason to doubt that this is the species we report here. It is found mainly in fishes of the family Sparidae, but has been reported in Zosterisessor ophiocephalus from the Black Sea by Nikolaeva (1975) and Gaevskaya and Korniychuk (2003).

Family Acanthocolpidae Lühe, 1906

Genus Stephanostomum Looss, 1899

Stephanostomum gaidropsari Bartoli \& Bray, 2001

This was reported as $S$. baccatum (Nicoll, 1910) by Oguz (1995) and Öktener (2005). This species was described by Bartoli and Bray (2001) from Gaidropsarus mediterraneus from the Gulf of Marseilles. This specimen is similar to the original description, with about 36 hooks (counts are not easy on flattened specimens) and a relatively short ejaculatory duct with prominent sclerotised 'cupolas'. The related $S$. pristis (Deslongchamps, 1824), also a parasite of gadiforms, was differentiated in two tables by Bartoli and Bray (2001) and this specimen fits $S$. gaidropsari in most characteristics, but it has a smaller sucker-ratio and the vitellarium is interrupted at the level of the gonads on both sides (cf unilateral in the description of $S$. gaidropsari). $S$. pristis is reported from eleven gadiform species (see Bartoli \& Bray, 2001; Gaevskaya, 2001) including G. vulgaris (see Looss, 1901b; Papoutsoglou, 1976), but not from $G$. mediterraneus.

Stephanostomum caducum (Looss, 1901) Manter, 1934

This was reported as Stephanostomum sp. by Oguz (1995) and Öktener (2005). There seems little doubt that the specimen of Stephanostomum (with 48 circum-oral spines) from Merluccius merluccius belongs to this species as it is morphologically indistinguishable from the forms described under this name by Looss (1901b), Lebour (1908), Nicoll (1914), Srivastava, Køie (1984) and Karlsbakk (1993). Later, Køie (1984) considered this species a synonym of another common parasite of gadiforms, $S$. pristis. This conclusion was not supported by Karlsbakk (1993) and Bartoli and Bray (2001), and this is followed here. $S$. caducum has been reported from eight species of gadid, but never from $M$. merluccius. In fact, we cannot trace any previous convincing records of adult Stephanostomum in this host. As pointed out by Bartoli and Bray (2001), the apparent record of S. cesticillum (Molin, 1858) from this host by Hristovski and Jardas (1991) is a result of a misalignment in the table. The host of $S$. solontschenki Parukhin, 1968 recorded as $M$. merluccius by Parukhin (1968) is corrected to M. capensis in later works (e.g. Parukhin, 1980). S. caducum is reported mainly in the north-eastern Atlantic, but was apparently originally found in the Adriatic off Trieste (Looss, 1901b).

\section{Family Fellodistomidae Nicoll, 1909}

Genus Monascus Looss, 1907

Monascus filiformis (Rudolphi, 1819) Looss, 1907

This species is a common parasite of carangid fishes and has frequently been reported in Trachurus trachurus in the Mediterranean and Black Seas and in the northern Atlantic (see Koie, 1979; Bray \& Gibson, 1980; Bartoli et al., 2005 and the Natural History Museum Host-parasite database on: http://www.nhm.ac.uk/research-curation/projects/hostparasites/database). The life-cycle was investigated by Koie (1979), who found that the cercariae were eaten by small fish, in which the worm matured, and was passed to piscivorous fishes by consumption. Later work has shown that the worm can also utilize medusae and chaetognaths as second intermediate hosts (Girola et al., 1992; Martorelli \& Cremonte, 1998).

Family Cryptogonimidae Ward, 1917

Genus Anisocladium Looss, 1902

Anisocladium fallax (Rudolphi, 1819) Looss, 1902

For comments see below.

\section{Genus Anisocoelium Lühe, 1900}

Anisocoelium capitellatum (Rudolphi, 1819) Lühe, 1900

Bartoli and Gibson (2000) redescribed and reviewed the cryp-togonimid parasites of Uranscopus scaber and came to the conclusion that Anisocladium fallax and Anisocoelium capitellatum are specific to this host, and that records from other fish species are either probably erroneous or represent accidental infections. They list earlier records of these species, and show that the worms have been widely reported in the Mediterranean and Black Seas. In the light of this study, some recent reports of these species need confirmation. Lozano et al. (2001) reported both species in the batrachoidid batrachoidiform Halobatrachus didactylus (Bloch \& Schneider) and in trachinid perciform Echiichthys vipera (Cuvier) from the southern Iberian Peninsula. Al-Bassel (2002) reported Anisocladium fallax in the mullid perciform Mullus surmuletus L. from the Mediterranean off Egypt.

\section{Discussion}

The Sea of Marmara is connected with the Black Sea to the northeast via the Bosporus and with the Aegean Sea via the Dardanelles to the southwest. Its area is small (about $280 \mathrm{x}$ 
$80 \mathrm{~km}, 11350$ square $\mathrm{km}$ ), but it is relatively deep (average depth is about $494 \mathrm{~m}$, maximum $1355 \mathrm{~m}$ ). Salinity averages $22 \%$ and is, therefore, not much greater than that found in the Black Sea $(17-18 \%$ in the upper layers Briggs, 1974) and is greatest near the Dardanelles. It is believed that the sea formed about 2.5 million years ago (late Pliocene Epoch). The fauna of this sea is, therefore, likely to be intermediate between that of the Black and Mediterranean Seas. The Black Sea is considered to have a depauperate fauna relative to the Mediterranean with only 20 to $29 \%$ as many species (according to Briggs, 1974). Ekman (1953) quoted figures on the mollusc fauna, showing that the Sea of Marmara harbours $59 \%$ as many species as the nearby Aegean Sea, whereas the relative figure for the Black Sea is $22 \%$. Similarly, Can and Belecenoğlu (2005) listed the fish fauna, with the Sea of Marmara harboring $64 \%$ (249) of the number of species found in the Aegean and wider Mediterranean (389), whereas the Black Sea has only $39 \%$ (151). The digenean fauna of the Sea of Marmara is not well enough studied for us to produce comparable figures, but it is noteworthy that nearly all species reported here are found in both the Black Sea and the Mediterranean Sea. None are found only in the Black Sea, and only two (Stephanostomum gaidropsari and $S$. caducum) have not been reported in the Black Sea. One species, Bucephalus marinus may be of Black Sea origin as, so far, its only Mediterranean report is from the Saronic Gulf off Greece.

Bartoli et al. (2005) studied the occurrence of fish digeneans throughout the Mediterranean Sea and Black Seas, based on the diversity index $\mathrm{M}=\mathrm{N} / \mathrm{N}^{\prime}$ ( $\mathrm{N}$ number of digenean species/N' number of fish species examined). The highest figure they discovered was $\mathrm{M}=3.8$ for the region off Corsica in the western Mediterranean. The figure we calculate from the present, admittedly small, sample is $\mathrm{M}=$ 1.4. This is lower than was found in the Black Sea $(\mathrm{M}=$ 2.2 and 2.7) or any of the eastern Mediterranean sites $(\mathrm{M}=$ 2.1 to 2.6), and closer to those found in the Adriatic Sea $(\mathrm{M}=0.6$ to 2.0$)$. Bartoli et al. (2005) thought that the relatively high figures in the eastern Mediterranean may reflect Lessepsian migration. According to Fischthal (1980) some Lessepsian fishes have brought their parasites with them and some have acquired local parasites. This can be expected to continue as more fish species establish themselves in the Mediterranean (Belecenoğlu et al., 2002). Bartoli et al. (2005) also thought that the diversity index might reflect the stability of the site and the pollution levels.

This study is the first of its kind in the Sea of Marmara and leaves many questions to be answered by further collection.

\section{References}

AKen'Ova, T. O. L., CRIBB, T. H., BrAY, R. A. (2005): The genus Helicometra Odhner, 1902 (Digenea: Opecoelidae) in Australian waters: Problems of identification of species and description of $H$. sprenti n. sp. Syst. Parasitol.,
63: $17-27$

Al-BAssel, D. A. M. L. (2002): Digeneans infecting the striped red mullet (Mullus surmuletus) from Egypt. Egypt. J. Zool., 38: $317-325$

Altunel, F. N. (1982): Seasonal changes and trematodes in mullet caught from the Aegean Sea. Ege University, Izmir, Assistant Professors Thesis, $56 \mathrm{pp}$.

BARTOLI, P., BRAY, R. A. (2001): Contribution to the knowledge of species of the genus Stephanostomum Looss, 1899 (Digenea: Acanthocolpidae) from teleosts of the Western Mediterranean, with the description of S. gaidropsari n. sp. Syst. Parasitol., 49: $159-188$

Bartoli, P., Bray, R. A., GiBSON, D. I. (xxxx): Four closely related but forgotten species of Rhipidocotyle Diesing, 1858 (Digenea: Bucephalidae) in fishes from European seas. Syst. Parasitol. (In press)

Bartoli, P., GiBson, D. I. (2000): Three little known acanthostomine digeneans from Uranoscopus scaber L. in the western Mediterranean. Syst. Parasitol., 46: 123 - 141 BARTOLI, P., GiBSON, D. I., BRAY, R. A. (2005): Digenean species diversity in teleost fish from a nature reserve off Corsica, France (Western Mediterranean), and a comparison with other Mediterranean regions. J. Natur. Hist., 39: $47-70$

BelecenoĞLu, M., TaskavaK, E., Kunt, K. B. (2002): Range extension of three Lessepsian migrant fish (Fistularia commersoni, Sphyraena flavicauda, Lagocephalus suezensis) in the Mediterranean Sea. J. Mar. Biol. Assoc. $U K, 83: 525-526$

BRAY, R. A., GiBSON, D. I. (1980): The Fellodistomidae (Digenea) of fishes from the northeast Atlantic. Bull. Brit. Mus. (Nat. Hist.), 37: $199-293$

BRAY, R. A., GIBSON, D. I. (1986): The Zoogonidae (Digenea) of fishes from the north-east Atlantic. Bull. Brit. Mus. (Nat. Hist.) (Zool. Ser.), 51: $127-206$

BRAY, R. A., GiBSON, D. I. (1990): The Lepocreadiidae (Digenea) of fishes of the north-east Atlantic: review of the genera Opechona Looss, 1907 and Prodistomum Linton, 1910. Syst. Parasitol., 15: 159 - 202

BRIGGS, J. C. (1974): Marine zoogeography. McGraw-Hill Book Company, New York.

CAN, A., BelecenoĞLU, M. (2005): Türkiye Denizlerinin Dip Baliklarinin Atlasi. Arkadaş Yayinevi, Ankara

DAWES, B. (1956): The Trematoda with special reference to British and other European forms. Cambridge: Cambridge University Press, 644 pp. (reprint of 1946 edition with corrections)

Dmitrieva, E. V., Gaevskaya, A. V. (2001): Parasitological aspects of mugilids mariculture and of their introduction to the Sea of Asov and the Black Sea. Ekologiya Morya, Kiev, 55: 73 - 78 (In Russian)

DolgikH, A. V., NAIDENOVA, N. N. (1968): On the fauna of helminths of Gaidropsarus mediterraneus (L.) from the Black Sea. Parazitologiya, 2: 448 - 453 (In Russian)

EKMAN, S. (1953): Zoogeography of the sea. Sidgwick \& Jackson, London

FARES, A., MAILlaRD, C. (1974): Recherches sur quelques Haploporidae (Trematoda) parasites des muges de Médi- 
terranée Occidentale: systématique et cycles évolutifs. $Z$. Parasitenkd., 45: 11 - 43

Fischthal, J. H. (1980): Some digenetic trematodes of marine fishes from Israel's Mediterranean coast and their zoogeography, especially those from Red Sea immigrant fishes. Zool. Scripta, 9: $11-23$

Fischthal, J. H., KunTZ, R. E. (1963): Trematode parasites of fishes from Egypt. Part V. Annotated record of some previously described forms. J. Parasitol., 49: 91 - 98

GaEvsKayA, A. V. (2001): Some comments to the description of Stephanostomum pristis (Deslongchamps, 1824) Looss, 1899 (Trematoda: Acanthocolpidae). Ekologiya Morya, 59: 17 - 20 (In Russian)

Gaevskaya, A. V., DMitrieva, E. V. (1993): Trematodes from the genus Saccocoelium, parasites of fish in the Black Sea. Vestnik Zoologii, 1: 75 - 78 (In Russian)

Gaevskaya, A. V., KorniychuK, Y. M. (2003): Parasitic organisms as a component of ecosystems of the Black Sea near-shore zone of Crimea. In EREMEEV, V. N. and GAEVSKAYA, A. V. (Eds) Modern condition of biological diversity in near shore zone of Crimea (Black Sea sector). Sevastopol: EKOSI-Gidrophizika, pp. 425 - 490

GaevsKayA, A. V., SolonchenKo, A. I. (1989): New data on the trematodes from the Black Sea fishes. Nauchnye Doklady Vysshei Shkoly Biologicheskie Nauki, 5: 43 - 47 (In Russian)

GIBSON, D. I., BRAY, R. A. (1982): A study and reorganization of Plagioporus Stafford, 1904 (Digenea: Opecoelidae) and related genera, with special reference to forms from European Atlantic waters. J. Natur. Hist., 16: $529-$ 559

Girola, C. V., Martorelli, S. R., SArdella, N. H. (1992): Presencia de metacercarias de Monascus filiformis (Digenea, Fellodistomidae) en hidromedusas del Océano Atlántico Sur. Rev. Chil. Hist. Nat., 65: 409 - 415

HristovsKI, N. D., JARDAS, I. (1991): Endohelminths of fishes from the mid-Dalmatian region of the Adriatic Sea (A review). Acta Adriat., 32: 671 - 681

IBRAGIMOV, S. R. (1988): Parasitofauna of fishes of Turkmen Gulf of the Caspian Sea. Izvestiya Akademii Nauk Turkmenskoi SSR, 2: 51 - 56 (In Russian)

KARLSBAKK, E. (1993): On the morphology and ecology of some digenean parasites of the four-bearded rockling (Enchelyopus cimbrius (L.)) (Gadidae) in Raunefjorden, western Norway. PhD Thesis. Bergen: University of Bergen, pp. 92

KøIE, M. (1978): On the morphology and life-history of Stephanostomum caducum (Looss 1901) Manter 1934 (Trematoda, Acanthocolpidae). Ophelia, 17: 121 - 133

KøIE, M. (1979): On the morphology and life-history of Monascus [= Haplocladus] filiformis (Rudolphi, 1819) Looss, 1907 and Steringophorus furciger (Olsson, 1868) Odhner, 1905 (Trematoda, Fellodistomidae). Ophelia, 18: $113-132$

KøIE, M. (1984): Digenetic trematodes from Gadus morhua L. (Osteichthyes, Gadidae) from Danish and adjacent waters, with special reference to their life-histories. $O p$ helia, 23: $195-222$
KORNIYCHUK, J. M. (1999): Phenotypic hostal differentiation of Helicometra fasciata (Rud., 1891) maritae. Ekologiya Morya, 49: 44 - 48 (In Russian)

KORNIYCHUK, J. M. (2000a): Morphological variability of genus Helicometra (Trematoda: Opecoelidae) maritae from the Black Sea. Ekologiya Morya, 51: 40 - 44 (In Russian)

KORNIYCHUK, J. M. (2000b): Interspecific interactions of trematodes in the gut of Symphodus tinca. Ekologiya Morya, 52: 34 - 38 (In Russian)

KORNIYCHUK, J. M. (2001): Structure of the trematode fauna of the Black Sea labrid fishes (Pisces: Labridae). Ekologiya Morya, 58: 32 - 36 (In Russian)

KovAL, V. P. (1966): Digenetic trematodes of the genus Plagioporus Stafford, 1904 from Ukrainian fishes. Visnyk Kyyivs Koho Universytetu, Seriya Biolohiyi, 8: 134 - 140 (In Ukrainian)

LEBOUR, M. (1908): Fish trematodes of the Northumberland coast. Report on the Scientific Investigations. Northumberland Sea Fisheries Committee, (1907), 23 - 67 Looss, A. (1901a): Ueber einige Distomen der Labriden des Triester Hafens. Zentralbl. Bakterios. Parasitenkd. Infektionskr. Hyg., 29: 398 - 405

Looss, A. (1901b): Ueber die Fasciolidengenera Stephanochasmus, Acanthochasmus und einige andere. Zentralbl. Bakterios. Parasitenkd. Infektionskr. Hyg., 29: 595 - 606, $628-634,654-661$

Lozano, C., Ubeda, J. M., De Rojas, M., Ariza, C., GueVARA, D. C. (2001): Estudio de digenidos de pèces marinos del sur de la Peninsula Iberica. Res. Rev. Parasitol., 61: $103-116$

LushCHINA, V. G. (1985): To the development cycle of Bucephalus marinus trematodes in fishes of Black Sea. Ekologiya Morya, 20: 48 - 50 (In Russian)

MACHKEVSKY, V. K. (1990): Helminthofauna of labrids in the places of cultivation of Black-Sea mussel, Mytilus galloprovincialis. Ekologiya Morya, 36: 75 - 82 (In Russian) MANTER, H. W. (1937): The status of the trematode genus Deradena with a description of six species of Haplosplanchnus Looss. In SCHULZ, R.-E.S. and GNYEDINA, M. P. (Eds): Papers on helminthology published in commemoration of the 30 year of K.I. Skrjabin, Moscow. Moscow: All-Union Lenin Academy of Agricultural Sciences, pp. $381-387$

Margolis, L., Esch, G. W., Holmes, J. C., Kuris, A. M., SCHAD, G. A. (1982): The use of ecological terms in parasitology (report of an ad hoc committee of the American Society of Parasitologists). J. Parasitol., 68: 131 - 133

MARKEVICH, A. P. (1951): Parasitic fauna of freshwater fish of the Ukrainian S.S.R. Kiev: Izdatel'stvo Akademii Nauk Ukrainskoi SSR, 388 pp. (In Russian: English translation, 1963)

Martorelli, S. R., Cremonte, F. (1998): A proposed three-host life history of Monascus filiformis (Rudolphi, 1819) (Digenea: Fellodistomidae) in the southwest Atlantic Ocean. Can. J. Zool., 76: 1198 - 1203

Mathias, P. (1926): Sur une nouvelle espèce de trématode Peracreadium perezi, nov. sp. Bull. Soc. Zool. Fr., 51: 353 $-356$ 
Merella, P., Garippa, G. (1998): Parasites of grey mullets from the Oristano lagoons (Sardinia). Parassitologia, 40: 106

Merella, P., GARIPPA, G. (2001): Metazoan parasites of grey mullets (Teleostea: Mugulidae) from the Mistras Lagoon (Sardinia, western Mediterranean). Scientia Marina, Barcelona, 65: $201-206$

MiKAILOV, T. K. (1958): Parasitofauna of Mugil saliens Risso of the Caspian Sea. Zoologicheskii Zhurnal, 37: 373 - 378 (In Russian)

Nahhas, F. M., Rhodes, D. Y., Seeto, J. (1997): Digenetic trematodes of marine fishes from Suva, Fiji. Family Haplosplanchnidae Poche, 1926: Description of new species, a review and an update. Technical Report. Marine Studies. The University of the South Pacific, 4: 1 - 87

NAIDEnOVA, N. N., KorniychuK, J. M., GaEvsKayA, A. V. (2002): Comments to the description of Bucephalus marinum Vlassenko, 1931 (Trematoda: Bucephalidae). Ekologiya Morya, 61: 25 - 28 (In Russian)

NICOLL, W. (1914): The trematode parasites of fishes from the English Channel. J. Mar. Biol. Assoc. UK, 10: $466-$ 505

NikolaeVA, V. M. (1975): [Family Zoogonidae Odhner, 1911]. In GREZE, V. N. (Ed.): [Identification key to parasites of vertebrates from the Black and Azov Seas]. Kiev: Naukova Dumka, pp. 115 - 116 (In Russian)

NiKolaEVA, V. M., SOlONCHENKO, A. I. (1970): [The helminth fauna of some bathypelagic fish in the Black Sea]. Biologiya Morya, Kiev, 20: 129 - 166 (In Russian)

OGUZ, M. C. (1995): The helminths in some teleost fishes in Mudanya coasts. Uludag University, Science Institution. $\mathrm{PhD}$ dissertation, $140 \mathrm{pp}$

ÖKTENER, A. (2005): A checklist of parasitic helminths reported from sixty-five species of marine fish from Turkey including two new records of monogeneans. Zootaxa, 1063: $33-52$

OSMANOV, S. V. (1940): [Studies on the parasite-fauna of fish from the Black Sea]. Uchenye Zapiski Leningradskogo Gosudarstvennogo Pedagogicheskogo Instituta imeni A I Gertsena, 30: 187 - 265 (In Russian)

Overstreet, R. M., Curran, S. S. (2005): Family Haploporidae Nicoll, 1914. In JONES, A., BRAY, R. A. \& GIBSON, D. I. (Eds): Keys to the Trematoda. Volume 2. Wallingford: CABI Publishing and the Natural History Museum, pp. $129-166$

PAPOUTSOGLOU, S. E. (1976): Metazoan parasites of fishes from Saronicos Gulf Athens - Greece. Thalassographica, 1: $69-102$

PARUKHIN, A. M. (1968): [New Trematoda representatives of the family Acanthocolpidae Lühe, 1909 in the food-fish of the South Atlantic.] Vestnik Zoologii. 2: 79 - 82 (In Russian)

PARUKHIN, A. M. (1980): [Characteristics of the helminthic fauna of the fish genus Merluccius of the world oceans and conformities of its distribution.] In MARKEVICH, A. P. et al.
(Eds): [Abstracts of the Ninth Conference of the Ukrainian Parasitological Society], Kiev: Naukova Dumka, Part 3: 141 - 142 (In Russian)

Pogorel'tSEVA, T. P. (1952): [Parasites of fish in the north-eastern part of the Black Sea]. Trudy Institutu Zoologii, Kiev, 8: 100 - 120 (In Ukrainian)

Pritchard, M. H., KRUSE, G. O. (1982): The collection and preservation of animal parasites. Lincoln: University of Nebraska Press, 141 pp.

Radujkovic, B. M., Orecchia, P., PAggi, L. (1989): Parasites des poissons marins du Montenegro: Digènes. Acta Adriatica, 30: 137 - 187

Reversat, J., Maillard, C., Silan, P. (1991): Polymorphismes phénotypique et enzymatique: intérêt et limites dans la description d'espéces d'Helicometra (Trematoda: Opecoelidae), mésoparasites de téléostéens marins. Syst. Parasitol., 19: 147 - 158

Reversat, J., Renaud, F., Maillard, C. (1989): Biology of parasite populations: the differential specificity of the genus Helicometra Odhner, 1902 (Trematoda: Opecoelidae) in the Mediterranean Sea demonstrated by enzyme electrophoresis. Inter. J. Parasitol., 19: 885 - 890

SAAD-FARES, A. (1985): Trématodes de poissons de cotes du Liban spécificité. Transmission et approche populationelle. $\mathrm{PhD}$ thesis. Université des Sciences et Techniques du Languedoc, pp. 435

SARABEEV, V. L., BAlbuenA, J. A. (2003): Morphological variability of Dicrogaster contracta Looss, 1902 (Digenea: Haploporidae) and its proposed synonymy with $D$. perpusilla Looss, 1902. Syst. Parasitol., 55: $25-31$

SAsal, P., Niquil, N., BARTOLI, P. (1999): Community structure of digenean parasites of sparid and labrid fishes of the Mediterranean Sea: a new approach. Parasitology, 119: $635-648$

SEY, O. (1970): Parasitic helminths occurring in Adriatic fishes. Part II (Flukes and Tapeworms). Acta Adriatica, 13: $3-15$

SEZEN-AKANDERE, Y. (1972): Istavrit baliklarindan elde edilen üç yeni. Acta Biol. Turc., 22: 89 - 94

SOLONCHENKO, A. I. (1976): [Helminth fauna of fishes from the Sea of Azov in the region of Primorsko-Akhtarska]. Biologiya Morya, Kiev, 39

SOLONCHENKO, A. I. (1982): [Helminth fauna of Azov Sea fishes]. Kiev: Naukova Dumka, 150 pp. (In Russian)

SOlONCHENKO, A. I., TKACHUK, L. P. (1985): Helminth infection of mullets from Azov-Black Sea basin. Ekologiya Morya, 20: 39 - 43 (In Russian)

SRIVASTAVA, L. P. (1966): A re-description of Stephanostomum caducum (Looss, 1901) (Digenea: Acanthocolpidae) from the intestine of Onos mustelus (L.). Annals and Magazine of Natural History, 9: 399 - 403

VLASENKO, P. (1931): [On the parasitic worm fauna of fishes of the Black Sea]. Trudy Karadahs'koyi Nauchnoyi Stantsiyi imeni T.I. Vyazems'koho, 4: 88 - 136 (In Russian and German) 